\title{
Towards student-centred solutions and pedagogical innovations in science education through co-design approach within design-based research
}

\author{
Maija Aksela1, 2 \\ ${ }^{1}$ National LUMA Centre Finland, University of Helsinki, Finland \\ ${ }^{2}$ The Unit of Chemistry Teacher Education, Department of Chemistry, University of Helsinki, Finland
}

The aim of this case study is to demonstrate how a co-design approach could be used within design-based research (DBR) with diverse multi-stakeholders in the LUMA $^{1}$ ecosystem to promote social creativity towards novel student-based solutions and pedagogical innovations. As a case, a national LUMA2020 development program (2019-2020), organized by the national LUMA Centre Finland and funded by the Finnish Ministry of Education and Culture, was studied in detail. The different data sources (e.g. an action plan, written observations) were analysed through qualitative content analysis. The Edelson's design-based research model used in the program offered a systematic framework or a map for codesigning both the action plan and its implementation. The co-design approach within the model was organised through three stages to engage all multistakeholders (altogether about three hundred participants) for it: (i) a research and societally oriented framework stage, (ii) a practical stage and (iii) a "bottom-up" stage in which teachers from 160 schools were active participants and professional key contributors. The co-design approach and the design decisions were facilitated by using guided face-to-face communication in small group work and digital creative learning spaces as a medium for social creative thinking. The co-designers were teachers, teacher educators, scientists or industry specialists in different stages. The co-design model used could be a way to bridge the newest research and innovations into praxis for supporting the curriculum at the school level and for promoting teachers' professional development by forming creative and diverse learning communities, in which all partners can learn from each other through sharing.

\section{Introduction}

“Together we are more!” (the LUMA ${ }^{1}$ motto)

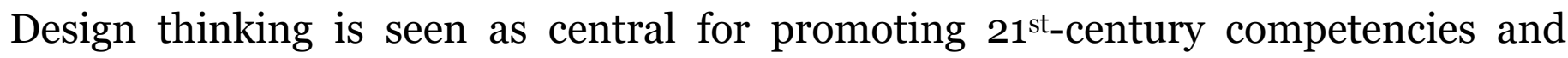
practices in education (e.g. Noweski et al, 2012; Kelly et al, 2019). Enhancing social creativity (e.g. Fischer et al, 2005) and learning through a co-design approach with multi-stakeholders (e.g. teachers, students, scientists, teacher educators or industry specialists), could be a way to tackle multi-faceted challenges in science education and

\footnotetext{
${ }^{1}$ LUMA is abbreviated from "luonnontieteet, the Finnish word for natural sciences, and "matematiikka", the Finnish word for mathematics. The national LUMA* Centre Finland referred to here as the LUMA ecosystem with 11 universities (www.luma.fi) and about fifty partners.
} 
its teacher training towards $2 \mathbf{1}^{\text {st-century }}$ competencies and student-centered solutions. Especially, creativity, collaboration and critical thinking are seen as necessary key competences.

There are many challenges in science education to be solved in the future. Science is not seen relevant enough for students themselves to study it at school or later on, especially in the developed countries (e.g. OECD, 2015). Their attitudes and interest have a big influence on their science enrolment behavior (e.g. Krapp \& Brenzel, 2011; Regan, 2015). Relevant vocational and societal perspectives of science are often unknown. Although Finnish youth have been one of the most skilful students in science globally, their interest to study science is often very low according to the PISA results (Finland and PISA, 2019). School science should be promoted more positively for all - "perhaps as a 'springboard' to new sources of interest and enjoyment." (OECD, 2015, 6). More scientific literacy for all is also needed in the future, for example, to solve global challenges (e.g. climate, energy, food and water).

In addition, the 21st-century learning demands have to be better taken into account in the design continuum of science teacher education. How to strengthen teachers' high professional role and teachers' life-long learning (e.g. Niemi \& IsoPahkala-Boureat, 2015)? How to get teachers opportunities to update their knowledge and skills concerning new research results in both science and its learning, thus to promote evidence-based teacher education for life-long learning in science (e.g. Aksela, 2010)? There is a need to bridge the gap between research and praxis (e.g. Juuti \& Lavonen, 2006; Aksela, 2010; Anderson \& Shattuck, 2012; Taber, 2017). Novel solutions for it are needed. Could the co-design approach within the designbased research (DBR) be a way to promote teachers' life-long learning?

Teachers are seen as key professional contributors to reforms (e.g. Roschelle \& Penuel, 2006). In Finland, teachers are valued and trusted as professionals in curriculum development, teaching and assessment (e.g. Niemi, Lavonen, Kallioniemi \& Toom, 2018). They also have a lot of professional freedom to decide how to teach and collaborate within curricula. According to Juuti et al (2017), successful teachers' professional development should be teacher-led, continuous (long-term), situated or connected to the classroom context, collaborative, and should include reflective practices. Design-based research (DBR) used as a design framework in the LUMA2020 program (see Section 2 for more details) has been earlier found as a useful way to promote teachers' or future teachers' professional development and growth (e.g. Sherin, 1998; Kelly, Lesh \& Baek, 2008; Pernaa \& Aksela, 2013; 
Vesterinen \& Aksela, 2013; Aksela \& Vihma, 2015; Aksela et al, 2016; Juuti, Lavonen \& Meisalo, 2016).

Facilitating the school-university partnership can be potential in contributing to the creation and translation of knowledge about teaching and learning (e.g. Baumfield \& Butterworth, 2007), as it is the main aims of the LUMA* ecosystem. It could be especially useful to engage teachers in a long-term collaborative research agenda (e.g. Reeves, 2000). Teachers often fail to adopt pedagogical innovations, if they are designed only by researchers (e.g. Talbert \& McLaughlin, 1999; Linn, 2006; Juuti \& Lavonen, 2006). They mainly make decisions on their teaching based on their own needs (e.g. Zhao et al. 2002). It may have a positive effect on student achievement if teachers have a more active role in the co-design processes. Promoting the knowledge production of teachers points out: (i) shared an understanding of the challenge, (ii) a willingness to change one's own perspective, (iii) a commitment to participate in the dynamics of the group (Orland-Barak \& Tillema, 2006).

The co-design approach focus in this study has led to high-quality teacher professional development for 21st-century learning used in a curriculum planning model (Kelly et al, 2019). Teachers can act successfully as co-designers with researchers (Roschelle \& Penuel, 2006). How to facilitate the co-design approach and social creativity within diverse multi-stakeholders (e.g. teachers, teacher educators, scientists or industry specialists) towards novel solutions and pedagogical innovations in science education as in the LUMA2020 program? There is a need for more understanding of the co-design approach (see Section 3 for more details) for it to be successful. The aim of this case study is to understand the co-design approach within Edelson's design-based research model in the LUMA* ecosystem (see Section 4). Its research policy points out that the purpose of design-based research (DBR) is to create student-centred solutions with diverse partners (e.g. schools, industry) and share them in all school levels (Research and development policy of the LUMA Centre Finland, 2018). This case study focuses on the following guiding questions: (i) how to facilitate the co-design approach?, (ii) who are the co-designers?, (iii) how can design decisions be executed in the process? And (iv) how to use the co-design process as a tool for promoting teachers' professional development? 


\section{Design-based research as a framework for the co-design approach}

Design-based research (DBR) has been found to be useful for developing new solutions and pedagogical innovations in education at least since the 1990s. By using it, educational practices are renewed through systematic, flexible and iterative analysis of design and development, and novel solutions are often produced for very complex challenges in authentic learning environments (e.g. Wang \& Hannafin, 2004, Van der Akker, Kelly, Lesh \& Baek, 2008). The term design-based research (e.g. Kelly, 2003; Juuti \& Lavonen, 2006; Anderson \& Shattuck, 2012) used in this paper has also been referred to in literature as (i) design experiments (e.g. Brown, 1992; Collins, 1992), (ii) design research (e.g. Cobb, 2001; Edelson, 2002), (iii) development research (e.g. Richey \& Nelson, 1996), or (iv) educational design research (e.g. Sandoval \& Bell, 2004; Van der Akker, Kelly, Lesh \& Baek, 2008, Vesterinen \& Aksela, 2013; Sandoval, 2014). Many kinds of successful models with various stages in practice have been reported (e.g. Lavonen \& Meisalo, 2002; Clements \& Battista, 2000). Usually, the design-based research has 7 to 9 different stages.

Design-based research usually gives us three kinds of information as a result of the study (Edelson, 2002): (i) information on the design product itself, (ii) the development process and (iii) the background theory or theories used in the development process. According to Edelson (2002) design methodology as a general design procedure provides guidelines for the process and describes (a) a process for achieving a class of designs, (b) the forms of expertise required, and (c) the roles to be played by the individuals representing those forms of expertise. As a result, concrete design solutions can be acquired: activities, materials, courses, learning environments, software or equipment for different levels (e.g. Brown \& Campione, 1994; Cognition \& Technology Group at Vanderbilt, 1997; Kelly, 2003). Some examples of design products are mentioned in the context of the LUMA ecosystem in Section 4.

Design-based research differs from traditional education research on the following eight areas: according to (i) the role of the participants (it involves different participants in the design to bring their differing expertise into producing and analyzing the design),(ii) the amount of social interaction (frequently it involves complex social interactions with participants sharing ideas, distracting each other 
etc.), (iii) flexibility of the process (it involves flexible design revision in which a tentative initial set is revised, depending on its success in practice), (iv) characterizing the findings (it involves looking at multiple aspects of the design and developing a profile that characterizes the design in practice), (v) location of research conducted (it often occurs in the buzzing, blooming confusion of real-life settings where most learning actually occurs), (vi) the complexity of the variables (it involves multiple dependent variables, including climate variables, outcome variables and system variables), (vii) unfolding of procedures (it involves flexible design revision in which a tentative initial set is revised, depending on its success in practice and (viii) the object of research (it focuses on characterizing the situation in all its complexity, much of which is not now a priori). (e.g. Barab \& Scquire, 2004; Collins, 1999; Aksela, 2005)

The following characteristics of good design-based research guide its design and implementation process (Dede, 2004; Design-Based Research Collective, 2003): (i) the correspondence of the design in the needs of practical and education policy,(ii) the intertwining of the aims of the chosen intervention and developed theories, (iii) the cyclicity of the development between design, implementation, analysis and redesign, (iv) the reliability of received results, (v) how the outcome of the development works in an authentic environment and (vi) how the received results adapt to earlier theories and practical implementations. The validity of design-based research is shown often through collaboration (e.g. the results checked by other co-examiner(s) as in this case study) and iteration, and the reliability through using various references for the research and by evaluating the usefulness of the research concerning education and learning (e.g. Design-Based Research Collective, 2003; Edelson, 2002).

Design-based research can include a strong collaborative approach with various partners - the so-called co-design approach (see Section 3 for more details) in this paper. It is used here within the design-based research framework, called the Edelson model (Edelson, 2002; see Section 4 for details). 


\section{Co-design approach within design-based research}

The co-design approach has been used since the early 1960s (Zamenopolous \& Alexiou, 2018). During the years it has been applied to various fields, for example from computer software design to architecture. The co-design approach is close to many other traditions of design, for example, participatory design (e.g. Ehn, 1992; Lee 2008), learner-centered design (e.g. Soloway et al., 1994) or co-creation (e.g. Prahalad \& Ramaswam, 2004). According to Zamenopolous \& Alexiou (2018), co-designers can have different roles in the process: they can facilitate or engage others in design tasks or share, collect, interpret or create knowledge, ideas and resources, and also engage at different stages of a design project. Different kinds of technology (e.g. Living labs) can be used for facilitating co-design and implementing activities (e.g. Andersen, Kanstrup \& Yndigegn, 2018).

The co-design approach has been found to be the most effective way to engage teachers in designing new practices at the school level (e.g. Penuel et al, 2007). Roschelle \& Penuel $(2006,1)$ define its use in education as "a highly-facilitated", team-based process in which teachers, researchers, and developers work together in defined roles to design an educational innovation, realize the design in one or more prototypes, and evaluate each prototype's significance for addressing a concrete educational need". The co-design approach can be seen as social (collective) creativity applied across the entire span of a design process (Sanders \& Stappers, 2008). Codesigners can be, for example, scientists, teacher educators, teachers, specialists from industry.

The co-design approach has been found useful at the school level. It provides an opportunity to match the curriculum goals of teachers (Tissenbaum et al, 2012; Kelly et al, 2019) and increase reflections and ownership by a teacher (Roschelle \& Penuel, 2006). Seven characteristic features are recommended to be taken into account when using co-design as an approach (Roschelle \& Penuel, 2006): (i) it takes on a concrete, tangible innovation challenge, (ii) the process begins by taking stock of current practice and classroom contexts, (iii) it has a flexible target, (iv) it needs $a$ bootstrapping event or process to catalyze the team's work, (v) it is timed to fit the school cycle, (vi) strong facilitation with well-defined roles is a hallmark of it, and (vii) there is central accountability for the quality of the products of co-design. 
Although co-design with the DBR framework has been found to be very useful in producing various relevant solutions and also theories, as mentioned in Section 2, challenges may occur when using it. According to Piirainen, Kolfschoten \& Lukosch (2009), five main challenges of collaboration can be found: creating shared understanding, balancing requirements of different stakeholders, balancing rigor and relevance in the process, organizing the collaboration effectively and creating ownership. If co-designers are novices, more guidance is needed to be successful (e.g. Chao, Saj \& Hamilton, 2010). In addition, the following things could be taken into account: (i) the process is often time-intensive (e.g. Rheinfrank et al.,1992; Roschelle \& Penuel, 2006), (ii) trust is needed on each other's knowledge and skills between codesigners (e.g. Shrader et al., 2001), (iii) criteria for success is needed between codesigners (e.g. Blomberg \& Henderson, 1990), (iv) understanding of goals, roles, and contributions of each participant (e.g. Shrader et al., 2001; Lee, 2008), (v) tight integration of curriculum (e.g. Roschelle \& Penuel, 2006) and (vi) understanding of negotiating shared frames during early design phases (e.g. Hey, Joyce \& Backman, 2007). Designers' frames seem to be effective on design decisions and the actions that they will take (e.g. Schön, 1983).

\section{Design-based research in the LUMA ecosystem}

The aim of the national LUMA* Centre Finland (network of 11 universities and 13 LUMA Centres with around 50 partners; referred to here as the LUMA ecosystem) is to develop novel, student-centred, research-based solutions and pedagogical innovations, and to distribute them both directly and indirectly to all science education and learning on different educational levels (Research and development policy of the LUMA Centre Finland, 2018). The co-design approach is seen as central for its design-based research (DBR) framework. The first LUMA Centre was built in the year 2003 in order to build a bridge for promoting collaboration between universities, schools and industry (e.g. Aksela, 2015).

Design-based research has been used broadly in promoting science education or its research-based science teacher education earlier in Finland (e.g. Lavonen \& Meisalo, 2002; Aksela, 2005; Juuti, 2005; Juuti \& Lavonen, 2006; Pernaa, 2013; Vesterinen \& Aksela, 2013; Juuti, Lavonen \& Meisalo, 2016; Juuti \& Lavonen, 2017). For example, relevant inquiry-based working instructions for science education have been designed collaboratively with diverse partners outside the university (e.g. 
Aksela, 2005; Aksela \& Boström, 2012; Aksela \& Ikävalko, 2016). A Finnish book on design-based research contains other examples for carrying out design-based research in education and in science teacher education in Finland (Pernaa, 2013).

Design-based research is mostly connected to the studies and theses in science teacher education in the LUMA ecosystem. In research concerning doctoral theses, for example, the following new solutions and pedagogical innovations are produced with the help of design-based research (SECO, 2019): (i) learning games and a framework for their evaluation, (ii) inquiry-based working instructions in collaboration with future teachers and the industry, (iii) a science club model for small children's inquiry-based education, (iv) a model for teachers' educational development by using inquiry-based learning and SOLO-taxonomy, (v) a collaborative and engaging model for teacher education that promotes inquiry-based education in-class teacher education, (vi) a course in the context of the Nature of Science for future teachers, (vii) problem-based and inquiry-based laboratory work activities into university education, and (viii) molecular modelling activities for instruction.

In practice, design-based research (DBR) can be carried out in various ways (see Section 2), and different models are available for supporting design decisions carried out during design-based research (e.g. Sandoval, 2014). In the LUMA2020 program, the design-based research framework, the so-called Edelson's model (Edelson, 2002) has been applied in practice. It has two main parts that guide the process and the decisions of the process: (a) theoretical problem analysis and (b) empirical problem analysis (see Figure 1). In the different parts of its cyclic development process, the socalled mixed methodology is often used in order to understand the object of development and its relevancy based on design decisions. For example, videorecordings, naturalistic observations, group interviews, concept maps, learning diaries, students' research reports or surveys can be used (e.g. Aksela, 2005) through the co-design approach, especially with teachers (teachers as reflectors or researchers) in the framework.

The co-design approach of Edelson's model (Edelson, 2002) can be carried out systematically in the following steps within the LUMA ecosystem. The framework is also used in the LUMA2020 program (Figure 1; the main phases are marked bold in the text): (i) mapping out the needs for the development process together with the participants (often called empirical problem analysis or a needs analysis: it can be done through a survey with teachers or a content analysis of learning materials or 
curriculum framework; the needs can be national needs and/or teachers' needs in science education), (ii) mapping out new research information concerning the chosen theme and synthesis (theoretical problem analysis), (iii) setting the goals of development together with different stakeholders based on the steps i) - ii) (goals for the activity), (iv) designing a pilot model together (e.g. practical activities) for the object of development based on chosen aims, and testing the pilot model with the target groups and refining it based on received results (a pilot model and testing it; an iterative design cycle)

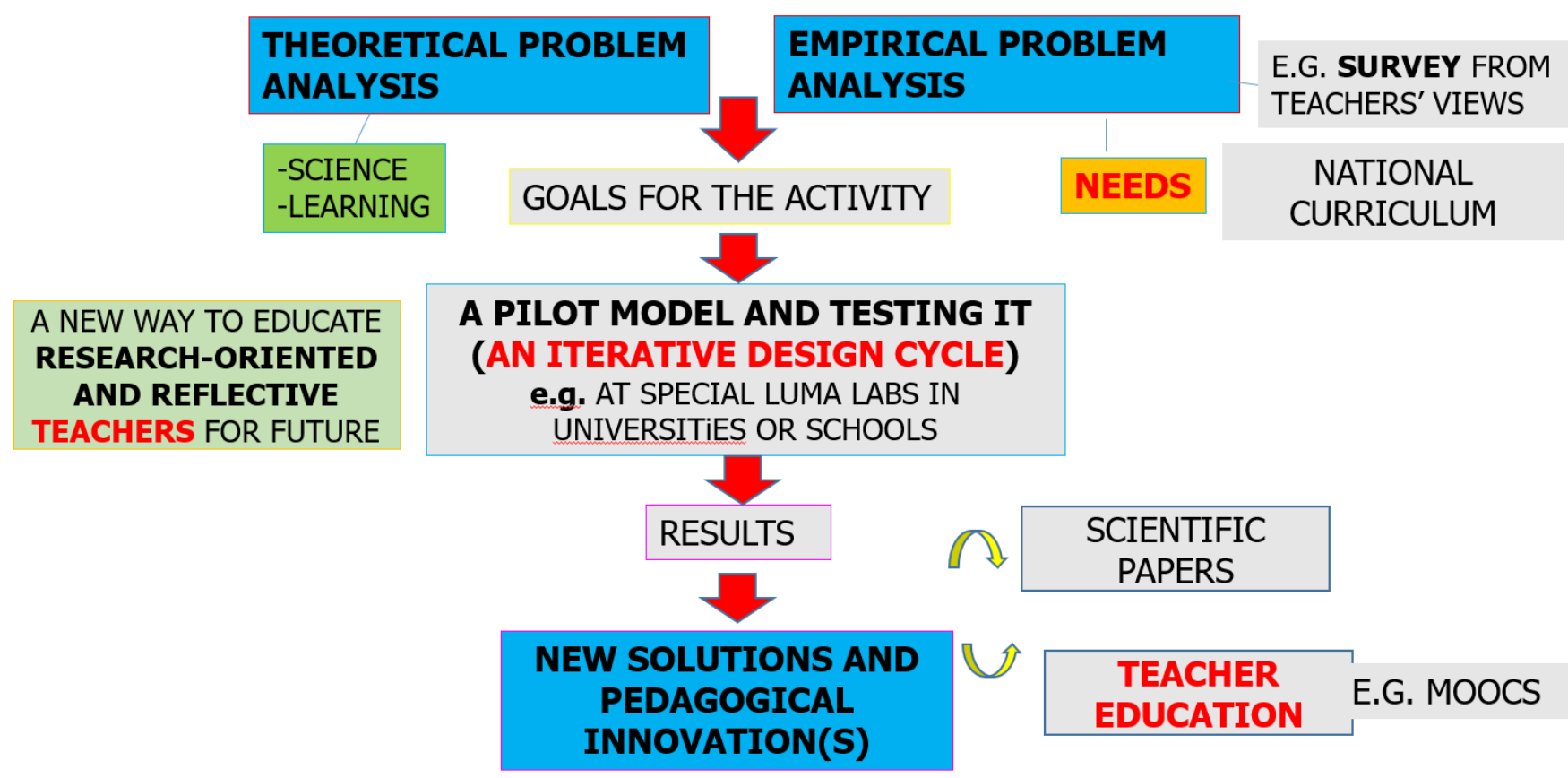

Figure 1. An example of the different phases of co-design within design-based research carried out in the Finnish LUMA ecosystem (see www.luma.fi) by applying Edelson's (2002) model. The different phases are marked bold in the text.'

(a cyclic model; teacher as a researcher or a reflector), (v) describing the outcome of development, and reporting it (results and pedagogical innovations) and (vii) spreading new openings and solutions, and offering education (e.g. through massive open online platforms, the so-called MOOCs) on them (teacher education; scientific papers). Usually, a researcher at a university, a teacher educator or a future teacher acts as a facilitator that carries out the synthesis and maps out new research information concerning the topic for other partners of the program or projects. In co-design meetings, steps (i) and (ii) are gone over together, and the aims for development and the model for implementation with timetables are arranged together. 
Besides formal learning environments at schools, non-formal learning environments (e.g. 15 LUMA labs), are often used during the co-design processes, include science and technology activities for children, youth and entire families, such as clubs, camps, parties and events, as well as the pursuit of hobbies at home. For example, in ChemistryLab Gadolin (one of the LUMA Labs), new openings in the contexts of everyday chemistry, sustainable chemistry, and development and modern technology are developed together with visiting school groups (Aksela et al, 2018) within industry collaboration (Aksela \& Ikävalko, 2016).

The distribution channels of the LUMA ecosystem include the education of future and current teachers at universities, events organized by universities and other partners, academic and popular multimedia publications, as well as international researcher exchange and education export. Innovations are spread to be used in nonformal, in-formal or formal learning environments. Research results will be published for the academic community in the form of articles in domestic and international peer-reviewed open access publications, conference presentations and proceedings, as well as scholarly works (bachelor's, master's and licentiate theses, doctoral dissertations).

The LUMA ecosystem has also channels of its own, such as the national LUMA days for teachers, International LUMAT Symposium and the peer-reviewed LUMAT (International Journal on Math, Science and Technology Education) online journal and the LUMAT-B online journal focused on conference and project proceedings, as well as the LUMA News section of the LUMA website. (Research and development policy of the LUMA Centre Finland, 2018). These acquired solutions are spread into teaching through teachers' pre-service and in-service education. As future teachers and teachers at schools have participated in designing, implementing and reflecting on the results of the development process, this acts as a novel model for organizing teacher education. An online book (Aksela, Oikkonen \& Halonen, 2018) gives a summary of examples of the projects that have been carried out at the University of Helsinki since the year 2003. 


\section{A case study in the context of the LUMA ecosystem}

The aim of this case study is to demonstrate how a co-design approach could be used within the design-based research (DBR), the Edelson's model (explained earlier in Section 4) with diverse multi-stakeholders (altogether about three hundred participants) in the LUMA* ecosystem to promote social creativity towards novel student-based solutions and pedagogical innovations focusing on the following guiding questions: (i) how to facilitate the co-design approach?, (ii) who are the codesigners?, (iii) how are design decisions in the process executed? In addition, the aim is to demonstrate (iv) how to use the co-design process as a tool for promoting teachers' professional development.

As a case, a national LUMA2020 development program (2019-2020) organized by national LUMA Centre Finland and funded by the Finnish Ministry of Education and Culture was studied in detail. The quality of the program has been guaranteed by using the best specialists in the evaluation process during the program and applying their advice on the design processes. The main aim, target groups and the design products of the LUMA2020 development program are summarised in Table 1. The main principles are given for the design process and the partners of the program can be found in Table 3 (Appendix 1). The organization of the program and responsibilities of different partners, and the stages of the program process can be found in Table 4 (Appendix 2).

The program is a continuum for the earlier national LUMA Suomi development program (2013-2019; www.luma.fi) funded by the Ministry of Education and Culture. The main focus of the program was the lower secondary level (6 to 16 years-olds). The focus of the LUMA2020 is especially on early childhood education and the upper secondary level, also in vocational education and training. The LUMA2020 program was chosen into this study because the co-design process framework has been documented in detail, and thus it is suitable for the content analysis method used (see later in detail). 
Table 1. The main aim, target groups and the design products of the LUMA2020 development program (the text is translated from the action plan written in the co-design stage 1 by the LUMA ecosystem).

\begin{tabular}{|c|c|c|}
\hline $\begin{array}{l}\text { The main aims of the LUMA program } \\
\text { (given from the policymakers) }\end{array}$ & $\begin{array}{l}\text { Target groups (given from } \\
\text { the policymakers) }\end{array}$ & $\begin{array}{l}\text { The design products in the } \\
\text { action plan designed by the } \\
\text { LUMA ecosystem }\end{array}$ \\
\hline $\begin{array}{l}\text { As the program ends at the end of } 2020 \\
\text { the program has: } \\
\text {-increased fascination towards studying } \\
\text { LUMA subjects and has improved the } \\
\text { quality of teaching and learning from } \\
\text { early childhood education to universities } \\
\text {-increased children and youths' interest } \\
\text { in LUMA subjects and their study and } \\
\text { career possibilities (individual, vocational } \\
\text { and societal relevance) } \\
\text { - strengthened the contents of teaching } \\
\text { and learning, and methods in teacher } \\
\text { training at faculties of science in } \\
\text { universities (early childhood education, } \\
\text { class teachers, special needs education, } \\
\text { subject teachers, teacher education that } \\
\text { universities offer, vocational teacher } \\
\text { education) } \\
\text { - promoted development work between } \\
\text { faculties of science / technical faculties } \\
\text { (according to the subject), teacher } \\
\text { training institutions and teacher training } \\
\text { schools, and university of applied } \\
\text { sciences and vocational teacher } \\
\text { education } \\
\text {-increased competences of staff and } \\
\text { their own education in these institutes } \\
\text { To develop: } \\
\text { 1) children and youth's formal learning } \\
\text { from early childhood education to } \\
\text { secondary education. } \\
\text { 2) children's, youth's and families' free- } \\
\text { time non-formal/informal science and } \\
\text { technology education and } 3 \text { ) the } \\
\text { competences of educational/ teaching } \\
\text { staff }\end{array}$ & $\begin{array}{l}\text { The target groups of the actions } \\
\text { include 3-19-year-old children } \\
\text { and youth - both girls and boys, } \\
\text { their guardians and } \\
\text { educational/teaching staff } \\
\text { working on different levels from } \\
\text { early childhood education to } \\
\text { universities. } \\
\text { The program includes the } \\
\text { development of LUMA subjects' } \\
\text { teaching and learning from } \\
\text { early childhood education to } \\
\text { universities, by stressing actions } \\
\text { especially from early childhood } \\
\text { education to the upper } \\
\text { secondary level (also in } \\
\text { vocational education and } \\
\text { training). }\end{array}$ & $\begin{array}{l}\text { New operating models are } \\
\text { developed in the program for e.g. } \\
\text { collaboration between early } \\
\text { childhood education / upper } \\
\text { secondary school / vocational } \\
\text { institution and universities, } \\
\text { working life collaboration, and } \\
\text { online courses. } \\
\text { Virtual clubs (packages) and online } \\
\text { courses for science and technology } \\
\text { education (national, shared } \\
\text { between universities). These are } \\
\text { exploited in order to strengthen } \\
\text { the continuity/path of science and } \\
\text { technology education from the } \\
\text { very young to the very old. } \\
\text { In addition, alongside the } \\
\text { implementation of the program, } \\
\text { theses and other research papers } \\
\text { are written. The final report of the } \\
\text { program that includes evaluation } \\
\text { will be finished at the end of } 2020 . \\
\text {-building a new national network } \\
\text { of LUMA development } \\
\text { communities (e.g. with } 50 \text { partners } \\
\text { in the LUMA ecosystem) } \\
\text {-strengthening the national LUMA } \\
\text { contact person's network of } \\
\text { municipalities. }\end{array}$ \\
\hline
\end{tabular}

The different data sources (an action plan as a main source (see Table 3 and Table 4 in Appendix 1 and Appendix 2), a memorandum of the co-design meeting in a wiki platform at the University of Helsinki, the materials in the open web page (http://2020.luma.fi) and written observations by a researcher) were analysed through qualitative content analysis to understand the co-design processes within the model. Applying content analysis from the texts (Huberman \& Miles, 1994), the 
central features of the co-design process and providing answers for the abovementioned questions have been presented as the results in Section 6.

The co-design approach was facilitated in three stages (the answer for the first research question): (i) a Research and societally oriented framework stage (see Section 6.1), (ii) a practical stage (see Section 6.2) and (iii) a "bottom-up" stage (see Section 6.3). As an example of the analysis, the form of the names of the stages are described (see Table 2):

Table 2. An example of the content analysis.

\begin{tabular}{|c|c|c|}
\hline The source 1 & The source 2 & $\begin{array}{l}\text { The name of the stage } \\
\text { formed from source } 1 \text { and } \\
\text { source } 2\end{array}$ \\
\hline $\begin{array}{l}\text { The action plan: } \\
\text { Table 3: LUMA Centre Finland (a network of } \mathbf{1 1} \\
\text { universities), In the implementation of the } \\
\text { program, LUMA Centre Finland carries out } \\
\text { development, education and } \\
\text { marketing/communication collaboration with e.g. } \\
\text { partners that are represented in the national } \\
\text { LUMA advisory board. } \\
=>\text { the role of the universities is to bring the } \\
\text { newest research to the co-design approach. } \\
=>\text { "a research oriented" }\end{array}$ & $\begin{array}{l}\text { The LUMA2020 webpage: } \\
\text { The names and organizations } \\
\text { of LUMA advisory board } \\
\text {-about } 50 \text { partners outside } \\
\text { of university (e.g. industry) } \\
\text { =>"societally oriented" }\end{array}$ & $\begin{array}{l}\text { a research and societally } \\
\text { oriented framework stage }\end{array}$ \\
\hline $\begin{array}{l}\text { A memorandum of the meeting (saved in the wiki } \\
\text { platform): } \\
\text { You can attend of the Facebook group to discuss } \\
\text { more about the program: } \\
\text { www.facebook.com/groups/LUMA2020. } \\
=>\text { the practical decisions of the action plan } \\
=>\text { "a practical stage" }\end{array}$ & $\begin{array}{l}\text { The written observations: } \\
\text { Few suggestions for a digital } \\
\text { platform (e.g. Wiki, Teams } \\
\text { and Facebook). } \\
\text { => the practical decisions of } \\
\text { the action plan } \\
=>\text { "a practical stage" }\end{array}$ & a practical stage \\
\hline $\begin{array}{l}\text { A memorandum of the meeting (saved in the wiki } \\
\text { platform): } \\
\text { The meetings and discussions with teachers will } \\
\text { be organised once a month... } \\
=>\text { the discussions of the program with teachers } \\
=>a \text { "bottom-up" stage }\end{array}$ & $\begin{array}{l}\text { The written observations: } \\
\text { The next teachers at each } \\
\text { school are written a plan in } \\
\text { the context of their school } \\
\text { curricula in a digital form } \\
\text { during a month. The co- } \\
\text { designing will continue with } \\
\text { the LUMA workers and other } \\
\text { teachers from different } \\
\text { schools during the next } \\
\text { meeting." } \\
\text { =>the teachers in each } \\
\text { school made their plan for } \\
\text { the program in details } \\
=>a \text { "bottom- } u p \text { " stage } \\
\end{array}$ & a "bottom-up" stage \\
\hline
\end{tabular}


The names for the main phases of the co-design approach by the Edelson model framework (empirical problem analysis, theoretical problem analysis) has been formed from the text in Table 3: “1) mapping out needs together with participants (empirical problem analysis, the so-called needs-analysis), 2) mapping out new research information concerning the chosen topic from sciences, their learning and teaching (theoretical problem analysis)." In addition, the name for the third main phase, a cyclic development process was named from the stages 3-6: "3) setting the aims for development together with the participants based on steps 1 and 2,4 ) planning a pilot model for the object of development (e.g. an activity, material) based on set aims, 5) testing the pilot model with the target group and refining the model based on received results (multiple steps), describing the development output and reporting and 6) spreading out new openings and solutions and offering education for these new topics. During the LUMA 2020 program, the development process is carried out at least in one cycle."

The written observations by a researcher from the stages (see Section 6.1, 6.2 and 6.3) were used to open more the texts in the main sources, for example, "The codesigners suggested few suggestions for a digital platform (e.g. Wiki, Teams, Facebook)." There it was mentioned only generally "digital platform" in the texts.

Because a researcher of this case study has been actively involved in the LUMA2020 program, a co-examiner has checked and accepted the written texts in this paper in order to increase the validity and the reliability of the case study.

\section{Results and discussion}

The co-design approach used within the design-based research framework, the Edelson's model (Edelson, 2002) is described in the following Sections (see Sections 6.1, 6.2 and 6.3) by providing answers to the following questions: (i) how to facilitate the co-design approach?, (ii) who are the co-designers?, (iii) how are design decisions executed in the process? The results for the question (iv) how to use the co-design process as a tool for promoting teachers' professional development? is presented in Section 6.4. 


\subsection{A Research and societally oriented framework stage}

The characteristics of good design-based research have guided the design and implementation process of the LUMA2020 program, as described in Section 2. The co-design approach was used in the designing of the general action plan for the framework given by the policymakers through the Edelson model's three main phases (see Figure 1):(i) empirical problem analysis (the needs for co-design), (ii) theoretical problem analysis (most novel research in science and science learning) and (iii) cyclic development process (actions for the decided goals). Co-designers in stage 1 were teacher educators and researchers from 11 universities (13 LUMA centres) by facilitating a national team (a director and a coordinator of the centre, a chair and a vice-chair of the board). The digital platform google docs was used for writing the action plan with different stakeholders around Finland. First, the director and the coordinator of the program wrote the framework of the action plan and then other members of the LUMA ecosystem continued the writing process.

The design decisions were accepted first by the board of LUMA Centre Finland (a member of each 13 LUMA Centres) and then by the steering group of the policymakers (including invited members from the universities: a director of the program, a project manager and four special experts). Design decisions were made based on the codesigners' expertise (e.g. most novel research in the field), international assessment programs (e.g. TALIS, TIMMS, PISA), the new national curriculum framework, experiences of the earlier national LUMA Suomi program (the program continuum for the earlier one) and the ideas collected through brainstorming from about 50 LUMA steering group members (e.g. industry foundations and pedagogical teacher organizations).

Four themes for the program were chosen through the co-design approach (i) sustainable development (e.g. climate change), (ii) math around us (e.g. math and art), (iii) technology around us (e.g. Al) and my LUMA (open for different integrated topics over subjects). A successful international StarT program (see https://start.luma.fi/en/) in which students are making projects, was decided to be used as a tool in practice at the school level. 


\subsection{A practical stage in the co-design approach used}

The co-design of the action plan for practice level in three phases of the Edelson's model (Edelson, 2002; Figure 1) was executed through a two-day design meeting, using mainly small group work and discussions. The main facilitators of the event were the project manager and the director of the program.

There were a lot of co-designers in the program: about 50 researchers, coordinators, project workers from the universities and a partner from industry facilitating by a national team (a director, a project manager, evaluation specialists, team leaders and chosen special researchers in science and technology education). They were divided into the teams of the chosen topics (see Section 6.1). The codesigners chose their own groups (e.g. math specialists participated in the math group). Each group had a group leader who facilitated discussion. As Roschelle \& Penuel (2006) mentioned, co-design needs a bootstrapping event or process to catalyze the team's work and well-defined roles. After group discussions, the project manager summarised different ideas together and wrote a memorandum of the decisions (saved in the wiki platform) and shared it with all the co-designers via email and also through the digital platform used.

Decision making was done in the co-design meeting, for example (i) about the digital platform (Teams selected) for co-design in detail, (ii) collecting evaluation materials from co-designers at school and (iii) a pre-questionnaire for co-designers at school before the first co-design meeting and timetables of the program. The codesigners suggested few suggestions for a digital platform (e.g. Wiki, Teams and Facebook). According to Andersen, Kanstrup \& Yndigegn, (2018), there are many challenges with using technology for facilitating co-design. Teams were chosen because it is easy to use and teachers are using it a lot in Finland.

\subsection{A "Bottom-up" stage in the co-design approach used}

In the model, teachers are seen as active participants, professional key contributors and collaborators with researchers, as Roschelle \& Penuel, (2006) found. The codesign of the previous action plan for supporting participating schools' and daycares' curricula based on empirical problem analysis (the needs of a school or a daycare), is seen as a critical phase of the co-design approach in the model. It is important to provide an opportunity to match the curriculum goals of teachers (cf. Tissenbaum et al, 2012; Kelly et al, 2019) and to increase reflections and ownership by a teacher (cf. 
Roschelle, Penuel \& Schechtman, 2006). According to Orland-Barak \& Tillema (2006) also important for teachers, are: (i) shared an understanding of the challenge, (ii) a willingness to change one's own perspective, (iii) a commitment to participate in the dynamics of the group.

The main co-designers in this stage were teachers, the so-called LUMA mentors from each school or daycare. Their needs based on the curriculum of their school were taken into account in the co-design of the program. Altogether 160 voluntary schools and kindergartens (two members from each one) were chosen to the program by using the open call. A small group works between the co-designers were used in the meetings for facilitating the co-design approach.

The project workers from each LUMA Centre in a university (one for each chosen theme) and possible partners from industry were seen as facilitators for the co-design approach. The digital platform (Teams) for the co-design in detail was chosen by the teachers because it is easy to use and familiar to the teachers.

The co-design meetings were decided to be organised once a month during the development process. The schedule (only one year) is, however, quite tight. The way in which we fit the co-design approach to the school cycle is critical for success (cf. Roschelle \& Penuel, 2006).

\subsection{The co-design process as a tool for promoting teachers' professional development}

The LUMA2020 program trusts the "bottom-up approach" for its success as in many earlier projects in which the DBR was found a useful way to promote teachers' or future teachers' professional development and growth (e.g. Vesterinen \& Aksela, 2013; Aksela \& Vihma, 2015; Aksela et al, 2016; Juuti, Lavonen \& Meisalo, 2016). The co-design phases above describe the factors pointed out (Juuti et al, 2017): teacherled, continuous (long-term), situated or connected to the classroom context, collaborative, and include reflective practices.

The systematic phases of the Edelson's design-based research model offer a learning environment, where teachers and all other participants can reflect and learn from one another, according to the 'learning community', especially in a cyclic development process of the model (Edelson, 2002; Figure 1). In practice, teacher educators as facilitators support teachers in the program to test the decided pilot model with their students, to collect research data and to reflect on the results in the 
monthly co-design meetings or through a digital platform that has been chosen together. Teachers as co-designers can also participate in writing the report and papers concerning the program or possible research facilitated by the teacher educators participating in the model.

\section{Conclusions}

The Edelson's design-based research model (DBR) used in the program can offer a systematic framework or a map for co-designing both the action plan and its implementation. Organizing the co-design approach within the model (Figure 1) through three main stages (see Sections 6.1, 6.2 and 6.3) with diverse multistakeholders (teachers, teacher educators, scientists or industry specialists as in the LUMA2020 program) could be fruitful for building relevant, novel practices in science education together if teachers are seen as active participants, key professional contributors and partners of researchers and teacher educators.

Guided face-to-face communication in the workshops or digital creative learning spaces as a medium for social, creative thinking could be useful for facilitating the codesign approach as in the LUMA2020 program. Familiar digital platforms can be used for planning, discussions, questions, sharing experiences and materials between codesigners within different stakeholders around Finland. Their role can be central for the co-design approach in practice when co-designers are far away from each other as in the LUMA2O20 program.

The co-design model could help to bridge the newest research and innovations from industry into praxis for supporting the curriculum at school level and for promoting teachers' professional development by forming creative and diverse learning communities, in which all partners can learn from each other through sharing. It can also promote novel teacher training together with partners outside the universities (e.g. industry). Thus, the co-design approach implementation can offer a new kind of an educational model for both pre-service and in-service training. Teachers or possibly also future teachers can act as "researching teachers" in projects and learn through their reflection facilitated by the teacher educators.

The used Edelson's design-based research model (Figure 1) can be helpful for especially the novices in research and sponsors -to whom research and the process for research-based solutions are new things. The implementation of the co-design approach may increase relevant collaboration between schools, universities and the 
industry and commerce, promote collaboration between participants that are often unknown to each other (e.g. researchers, teacher educators, industry specialists, teachers, representatives from the educational administration and future teachers).

The limitation of this case study is the use of only a few documents as the main source. In order to better understand the successful co-design approach within design-based research with diverse multi-stakeholders, more research is needed to understand the different roles of the stakeholders (e.g. facilitators; teachers as codesigners), early design frames, design decision processes, creative learning spaces (e.g. digital platforms) for promoting the co-design approach and the views of its advantages and challenges for co-designers.

\section{Acknowledgements}

This article is based on my keynote presentation of the design-based research method and fruitful discussions on November $8^{\text {th }}, 2018$ in the symposium called "Contemporary approaches to research on mathematics, science, health and environmental education" at Deakin University, Australia. The best acknowledgements to the STEM research group at Deakin University, all LUMA collaborators (https://www.luma.fi) and especially my research team (https://www.helsinki.fi/en/researchgroups/seco) who has collaborated with me since the year 2005, and especially to a co-examiner, Topias Ikävalko.

\section{References}

Aksela, M. (2005). Supporting meaningful chemistry learning and higher-order thinking through computer-assisted inquiry: a design research approach. Helsinki: The University of Helsinki.

Aksela, M. K. (2010). Evidence-based teacher education: becoming a lifelong research-oriented chemistry teacher? Chemistry education research and practice, 11(2), 84-91.

Aksela, M., \& Boström, M. (2012). Supporting Students' Interest through Inquiry-Based Learning in the Context of Fuel Cells. Mevlana International Journal of Education, 2(3), 53-61.

Aksela, M. K. \& Vihma, L. J. (2015). Uudenlainen yhteisöllinen opettajankoulutus LUMAekosysteemissä elinikäisen oppimisen tukena (In English: Novel collaborative teacher education for long-life learning in the LUMA ecosystem). LUMAT: Luonnontieteiden, matematiikan ja teknologian opetuksen tutkimus ja käytäntö 3(6), pp. 711-720. https://www.lumat.fi/index.php/lumat-old/article/view/91

Aksela, M. K. (2015). Luma Centre Finland: The Finnish model to educate teachers in math, science and technology. In U. Heinichen, \& O. J. Haupt (Eds.), 10 Jahre LeLa Jahrestagung (pp. 16-18). Berlin: LernortLabor, Bundesverband der Schülerlabore.

Aksela, M., \& Ikävalko V-M. (2016). How to promote relevant practical work in science education through a non-formal learning environment? Science Education Research and Practical 
Work: A collection of invited papers inspired by the 23rd Symposium on Chemistry and Science Education held at the TU Dortmund University, May 26-28, 2016. Eds. Eilks, I, Markic, S. \& Ralle, B. Aachen: Shaker, 2016.

Aksela, M. K., Vartiainen, J. L., Tuomisto, M., Turkka, J. S., Pernaa, J. I. S., \& Tolppanen, S. (2016). Promoting Meaningful Science Teaching and Learning Through ICT in the Finnish LUMA Ecosystem. In H. Niemi, \& J. Jia (Eds.), New Ways to Teach and Learn in China and Finland: Crossing Boundaries with Technology (pp. 255-278). Frankfurt am Main: Peter Lang.

Aksela, M., Oikkonen, J., \& Halonen, J. (Eds.) (2018). Collaborative Science Education at the University of Helsinki since 2003: New Solutions and Pedagogical Innovations for Teaching from Early Childhood to Universities. Helsinki: Unigrafia Oy. https://www.helsinki.fi/sites/default/files/atoms/files/isbn-978-951-51-4089-0.pdf

Aksela, M. K., Pernaa, J. I. S., Blomgren, P. I. A., \& Rautiainen, I. M. (2018). Collaborative science education at the University of Helsinki: ChemistryLab Gadolin: a science lab as an inspiring environment for learning, development and research since 2008. Helsinki: The University of Helsinki. https://www.helsinki.fi/sites/default/files/atoms/files/isbn-978-951-514506-2.pdf

Anderson, T., \& Shattuck, J. (2012). Design-based research a decade of progress in education research? Educational researcher, 41(1), 16-25.

Barab, S., \& Squire, K. (2004). Design-based research: Putting a stake in the ground. Journal of the Learning Sciences, 13(1), 1-14.

Baumfield, V. \& Butterworth, M. (2007). Creating and translating knowledge about teaching and learning in collaborative school-university research partnerships: an analysis of what is exchanged across the partnerships, by whom and how. Teachers and Teaching, 13:4, 411427.

Blomberg, J. L., \& Henderson, A. (1990). Reflections on participatory design: Lessons from the Trillium Experience. Proceedings of CHI 9o, (pp. 353-359). New York, NY:ACM.

Brown, A. L. (1992). Design experiments: Theoretical and methodological challenges in creating complex interventions in classroom settings. The Journal of the Learning Sciences, 2(2), 141178.

Brown, A., \& Campione, J. (1996). Psychological theory and the design of innovative learning environments: On procedures, principles, and systems. In L. Schauble \& R. Glaser (Eds.), Innovations in learning: New environments for education (pp. 289-325). Mahwah, NJ: Lawrence Erlbaum Associates.

Clements, D. H. \& Battista, M. T. (2000). Designing Effective Software. In A. E. Kelly \& R. A. Lesh. (Eds.) Handbook of Research Design in Mathematics and science Education, (pp. 761-776). New Jersey, Lawrence Erlbaum Associates.

Cobb, P. (2001). Supporting the improvement of learning and teaching in social and institutional context. In S. Carver \& D. Klahr (Eds.), Cognition and instruction: Twenty-five years of progress (pp. 455-478). Cambridge, MA: Lawrence Erlbaum Associates.

Cognition and Technology Group at Vanderbilt. (1997). The Jasper project: Lessons in curriculum, instruction, assessment, and professional development. Mahwah, NJ: Erlbaum.

Collins, A. (1992). Towards a design science of education. In E. Scanlon \& T. O'Shea (Eds.), New directions in educational technology (pp. 15-22). Berlin: Springer.

Collins, A. (1999). The changing infrastructure of education research. In E. Lagemann \& L. Shulman (Eds.), Issues in education research (pp. 289-298). San Francisco: Jossey-Bass.

Dede, C. (2004). If design-based research is the answer, what is the question? A commentary on Collins, Joseph, and Bielaczyc; diSessa \& Cobb; and Fishman, Marx, Blumenthal, Krajcik \& 
Soloway in the JLS special issue on design-based research. Journal of the Learning Sciences, 13(1), 105-114.

The Design-Based Research Collective. (2003). Design-based research: An emerging paradigm for educational inquiry. Educational Researcher, 5-8.

Edelson, D. C. (2002). Design research: What we learn when we engage in design. The Journal of the Learning Sciences, 11, 105-121.

Ehn, P. (1992). Scandinavian design: On participation and skill. In P. S. Adler \& T. A. Winograd (Eds.), Usability: Turning technologies into tools (pp. 96-132). New York: Oxford University Press.

Finland and PISA, (2019). Finnish Ministry of Education and Culture. Finland and PISA. https://minedu.fi/en/pisa-en

Fischer, G., Giaccardi, E., Eden, H., Sugimoto, M., Ye,Y. (2005) Beyond binary choices: Integrating individual and social creativity. International Journal of Human-Computer Studies, 63(4-5), 482-512.

Hey, J.,Joyce, C. K. \& Beckman, S. L. (2007). Framing Innovation: Negotiating Shared Frames During Early Design Phases. Journal of Design Research, 6(1), 77-99.

Huberman, A. M., \& Miles, M. B. (1994). Data management and analysis methods. In N. K. Denzin \& Y. S. Lincoln (Eds.), Handbook of qualitative research (pp. 428-444). Thousand Oaks, CA, US: Sage Publications, Inc.

Kelly, A. E. (2003). Research as design. Educational Researcher, 32(1), 3-4.

Kelly, A. E., Lesh, R. A., \& Baek, J. Y. (Eds.) (2008). Handbook of design research in methods in education. Innovations in science, technology, engineering, and mathematics learning and teaching. New York, NY: Routledge.

Kelly, N., Wright, N., Dawes, L., Kerr, J., \& Robertson, A. (2019). Co-design for Curriculum Planning: A Model for Professional Development for High School Teachers. Australian Journal of Teacher Education, 44(7).

Krapp, A. \& Prenzel, M. (2011) Research on Interest in Science: Theories, methods, and findings, International Journal of Science Education, 33(1), 27-50.

Juuti, K., \& Lavonen, J. (2006). Design-based research in science education: One step towards methodology. Nordina, 4, 54-68.

Juuti, K. (2005). Towards primary school physics teaching and learning: design research approach. Helsinki: University of Helsinki.

Juuti, K., Lavonen, J. \& Meisalo, V. (2016). Pragmatic Design-based Research -Designing as a Shared Activity of Teachers and Researchers. Iterative Design of Teaching-Learning Sequences: Introducing the Science of Materials in European Schools. Psillos, D. \& Kariotoglou,P. (eds.). Dordrecht: Springer Science + Business Medisa, 35-46.

Lavonen, J. \& Meisalo, V. (2002). Research-based design of learning materials for technologyoriented science education. Themes in Education, 3, 107-131.

Lavonen, J., Inkinen, J., Juuti, K., Salmela-Aro, K., Krajcik, J., \& Schneider, B. (2017). The influence of an international professional development project for the design of engaging secondary science teaching in Finland. In M. K. Mhlolo, S. N. Matoti, \& B. Fredericks (Eds.), Book of Long Papers:25th Annual Meeting of the Southern African Association of Researchers in Mathematics Science \& Technology Education (SAARMSTE) (pp. 206-220). Johannesburg: SAARMSTE.

Lee, Y. (2008). Design participation tactics: The challenges and new roles for designers in the codesign process. Co-design, 4(1), 31-50.

Niemi, H., Lavonen, J., Kallioniemi, A., \& Toom, A. (2018). The Role of Teachers in the Finnish Educational System: High Professional Autonomy and Responsibility. In H. Niemi, A. 
Toom, A. Kallioniemi, \& J. Lavonen (Eds.), The Teacher's Role in the Changing Globalizing World: Resources and Challenges Related to the Professional Work of Teaching (pp. 47-61). Leiden: Brill Sense.

Niemi, H. \& Isopahkala-Bouret, U. (2015) Persistent Work for Equity and Lifelong Learning in the Finnish Educational System. The New Educator, 11:2, 130-145.

OECD $(2015,6)$ PISA 2015. PISA results in focus. http://www.oecd.org/pisa/pisa-2015-results-infocus.pdf

Osman Andersen, T., Kanstrup, A. M., \& Yndigegn, S. L. (2018). Three living labs in Denmark: Challenges with co-design and implementation of health IT. I A. Bygholm, L. PapeHaugaard, K. Niss, O. Hejlesen, \& C. Zhou (red.), Proceedings from The 16th Scandinavian Conference on Health Informatics 2018 Aalborg, Denmark August 28-29, 2018 (s. 1-6). Linköping University Electronic Press. Linköping Electronic Conference Proceedings, Bind. 151

Noweski, C., Scheer, A., Büttner, N., von Thienen, J., Erdmann, J., \& Meinel, C. (2012). Towards a paradigm shift in education practice: Developing twenty-first century skills with design thinking. In H. Plattner, C. Meinel, \& L. Leifer (Eds.), Design thinking research: Understanding innovation (pp. 71-94). Berlin, Heidelberg: Springer-Verlag.

Penuel, W. R., Roschelle, J., \& Shechtman, N. (2007). Teachers: An analysis of the co-desing process. Learning, 2(1), 51-74.

Pernaa, J. (Ed., 2013). Kehittämistutkimus opetusalalla (In English: Design-based research in education in English). Juva: Bookwell Oy.

Pernaa, J., \& Aksela, M. (2013). Model-Based Design Research: A Practical Method for Educational Innovations. Advances in Business-Related Scientific Research Journal, 4(1), 71-83.

Prahalad, C.K. \& Ramaswamy, V. (2004). Co-Creation Experiences: The Next Practice in Value Creation. Journal of Interactive Marketing, 18(3), 5-14.

Regan, E. \& DeWitt, J., (2015). Attitudes, interest and factors influencing STEM enrolment behaviour: an overview of relevant literature. In E.K. Henriksen, J. Dillon and J. Ryder (Eds.), Understanding student participation and choice in science and technology education. (pp. 6388). Dordrecht: Springer.

Research and development policy of the LUMA Centre Finland, (2018). LUMA Centre Finland, http://www.luma.fi

Richey, R. C., \& Nelson, W. A. (1996). Developmental research. In D. Jonassen (Ed.), Handbook of research for educational communications and technology (pp. 1213-1245). London: Macmillan.

Rheinfrank, J. J., Hartman, W. R., \& Wasserman, A. (1992). Design for usability: Crafting a strategy for the design of a new generation of Xerox copiers. In P. S. Adler \& T. A. Winograd (Eds.), Usability: Turning technologies into tools (pp. 15-40). New York: Oxford University Press.

Roschelle, J., DiGiano, C., Koutlis, M., Repenning, A., Phillips, J., Jackiw, N., et al. (1999). Developing educational software components. IEEE Computer, 32(9), 50-58.

Roschelle, J., \& Penuel, W. R., (2006). Co-design of innovations with teachers: Definition and dynamics. Proceedings of the 7th International Conference on Learning Sciences, 606612.

Sanders, E. \& Stappers, P.J. (2008) Co-creation and the new landscapes of design. CoDesign, 4(1), $5-18$.

Sandoval, W. A., \& Bell, P. (2004). Design-based research methods for studying learning in context: Introduction. Educational Psychologist, 39(4), 199-201.

Sandoval, W. (2014). Conjecture mapping: An approach to systematic educational design research. Journal of the Learning Sciences, 23(1), 18-36. 
SECO, (2019). SECO (Science and Chemistry Education Collaboration) research group at University of Helsinki, Finland. https://www.helsinki.fi/seco

Shrader, G., Williams, K., Lachance-Whitcomb, J., Finn, L.-E., \& Gomez, L. (2001). Participatory design of science curricula: The case for research for practice. Paper presented at the Annual Meeting of the American Educational Research Association, Seattle, WA.

Sherin, M.G. (1998). Developing teachers' ability to identify student conceptions during instruction. In S. B. Berenson, K. R. Dawkins, M. Blanton, W. N. Coulombe, J. Kolb, K. Norwood, \& L. Stiff (Eds.), Proceedings of the Twentieth Annual Meeting of the North American Chapter of the International Group for the Psychology of Mathematics Education (pp. 761-767). Columbus, OH: ERIC Clearinghouse for Science, Mathematics, and Environmental Education.

Soloway, E., Guzdial, M., \& Hay, K. E. (1994). Learner-centered design: The challenge for HCI in the 21st century. Interactions, 1(2), 36-47.

Schön, D.A. (1983). The Reflective Practitioner. New York, NY: Basic Books.

Taber, K.S. (2017). Science Education as a Field of Scholarship. In: Taber K.S., Akpan B. (Eds). Science Education. New Directions in Mathematics and Science Education. SensePublishers, Rotterdam.

Talbert, J.E. \& M.W. McLaughlin (1999). Assessing the School Environment: Embedded Contexts and Bottom-Up Research Strategies," in S.L. Friedman \& T.D. Wachs (Eds.) Measuring Environment Across the Life Span, (pp. 197-227). Washington DC: American Psychological Association.

Tissenbaum, M., Lui M., Slotta, J. \& D. (2012). Co-Designing Collaborative Smart Classroom Curriculum for Secondary School Science. Journal of Universal Computer Science, 18(3), 327-352.

Zamenopoulos, T. and Alexiou, K. (2018). Co-Design as Collaborative Research in Facer, K and Dunleavy, K. (eds.) Connected Communities Foundation Series. Bristol: University of Bristol/AHRC Connected Communities Programme. https://connected-communities.org/wpcontent/uploads/2018/07/Co-Design_SP.pdf

Wang, F. \& Hannafin, M. J. (2004). Using design-based research in design and research of technology-enhanced learning environments. Paper presented at the Annual Meeting of the American Educational Research Association, San Diego, CA.

van der Akker, J., Gravemeijer, K., McKenney, S., \& Nieveen, N. (2006). Educational design research. London: Routledge. Whitehurst.

Vesterinen, V-M., \& Aksela, M. (2013). Design of Chemistry Teacher Education Course on Nature of Science. Science \& Education, 22(9), 2193-2225. 


\section{Appendix 1}

Table 3. The main principles given for the design process and the partners of the program (the text translated from the action plan written during the co-design phase 1 by the LUMA ecosystem).

\section{The main principles for the design process}

In the program, measures are carried out in two measure entities that in practice come together as one logical and intact program: A) The sparking of motivation to learn and its support, on the one hand in "classrooms" in different education levels and on the other hand during children, youth and families' free time. B) The development of preservice and in-service education for teachers who teach math, environmental studies, biology, physics, chemistry and geography in different levels.

The program focuses on four focal points: 1 . vocational and societal relevance in education

2. differentiated instruction, 3. the promotion of 'engineering skills' (technology education) and 4. creative, engaging work (e.g. embodied and drama-based learning)

The common thread in the implementation of the LUMA 2020 program consists of a differentiated viewpoint that promotes mathematical and scientific literacy in a crosscurrical way (uniting different fields and subjects, STEAM), in the spirit of multidisciplinary learning entities and theme learning according to the national core curricula.

Both 'face-to-face' measures and virtual measures are carried out in the program, which have effectiveness broadly all over Finland.

The program complements the national projects and actions that LUMA Centre Finland has already carried out (see above).

LUMA 2020 program complements the national learning path for science and technology education.

The program promotes educational continuity of educational and teaching staff (early childhood educators, class teachers, special needs teachers, subject teachers, guidance counselors and vocational teachers).

Spreading out occurs for example by educating future teachers and in-service teachers, in events organized by universities and other partners, in the form of academic and popular multimedia publication, and internationally also through researchers exchange and education export. Development can be published also for the scientific community and in the form of theses. The aim is to include this program as a part of partners' events such as events of educational organizations, already in Fall 2019 and especially in 2020 .

LUMA Centre Finland produces only such new data in its program that can be published using an open license. LUMA Centre Finland publishes all data from its program in a web platform that it operates and maintains this data at least until the program comes to its end, but depending on the possibilities data is available indefinitely.
The partners of the program or activity

LUMA Centre Finland (a network of 11 universities), where 13 regional LUMA Centres operate. University of Helsinki is in charge of the administration of the network and it is the responsible organizer of the LUMA 2020 program and other universities are its subcontractors.

1)Nationally:

In the implementation of the program, LUMA Centre Finland carries out development, education and marketing/communication collaboration with e.g. partners that are represented in the national LUMA advisory board. In addition, LUMA Centre Finland strengthens collaboration with other national networks.

2)Regionally/locally:

With Regional State Administrative Agencies, Education Division/ Education Consortiums of municipalities and individual learning environments (units of early childhood education, units of primary and lower secondary education, units of upper secondary education, units of vocational education and training) and e.g. with libraries, youth activities, sports clubs, hobby groups and parents' associations. In individual learning environments, the aim is to get especially tutors and guidance counselors to participate actively in development. The aim is to also collaborate with university alumni already in the working life.

LUMA Centre Finland strengthens especially the so-called LUMA municipal network that has been created in the LUMA FINLAND program during 2014-2016.

In the concrete implementation of the measures of the program, the members of teams collaborate in the usual way in their universities with teacher educators, researchers and other staff as well as with basic degree students and postgraduate students. 
The implementation of the program is evaluated throughout the entire process. Evaluation gives us information on how the implementation of the program is progressing concerning the aims set for development. Evaluation is divided into three areas: 1 . Evaluating the extent/activity of operations and its quality

2. Evaluation of the effectiveness of operations

3. Evaluation of different actions (development of formal education, free-time activities and teacher's competences)

In the first area of evaluation, the amounts of operational units (e.g. unit of early childhood education, primary and lower secondary school, upper secondary school, vocational institution), teachers, pupils, students and parents participating in the program are monitored during the entire process. Measuring instruments are developed for evaluating the quality of the operations and these instruments are based on surveys for guardians, the school and students, used in the PISA and TIMMS surveys, on the TALIS teacher survey and on national surveys such as the measuring instruments for entrepreneurship education. The approach makes it possible that the effectiveness of actions can be compared with the starting point (results of PISA, TALIS and TIMMS surveys). The evaluations rely on qualitative and quantitative sections. In addition, it's possible to carry out interviews for students and teachers.

Results acquired from different areas of the evaluation program are analyzed also vertically by combining results from various areas. This is how a plausible bigger picture can be formed of the effectiveness of the different operational processes and its quality. This way it is possible to reliably recognize good and unsuitable practices from one another and justifiable solutions can be made for developing actions and increasing the effectiveness. 


\section{Appendix 2}

Table 4. The organization of the program and responsibilities of different partners and the stages of the program process the text translated from the action plan written during the co-design phase 1 by the LUMA ecosystem).

\section{The organization of the program and responsibilities of different partners}

The Finnish Ministry of Education and Culture assigns a steering group for the program that aligns the implementation of the program, and the following experts, the so-called core group are a part of the steering group.

The responsible leader is the Director of LUMA Centre Finland from the University of Helsinki.

Experts with their special expertise areas in the planning of the program, its implementation and evaluation include professors (science education, math education, technology education and the evaluation of education) and senior lecturers as representatives of vocational teacher education colleges. Experts participated for example by giving inserts/examples that guided learning. Those working alongside the program can consult experts and ask them about their views and they can receive support as the program is being implemented.

In addition to experts, the program's project manager supports the responsible leader and directs the implementation of the program and is in charge of the national marketing/communication and collaboration with various partners. The mentioned experts and the project manager together form the core group of the program.

The LUMA 2020 program is implemented nationally within the framework of the four themes of the StarT program. A team is formed for each theme, the so-called theme team. Each LUMA Centre participates in the implementation of each theme, in other words they participate in four theme teams; in the joint planning/forming of measures and in their individual geographical operations area, where they implement measures. In each of the LUMA Centres at least one worker works full time with the program or a couple of workers work part time on the program. The leaders of theme teams work in close collaboration together with the project manager.

In addition, there is a team for the evaluation of the program, and it includes an evaluation specialist and the leaders of the four theme teams. The project manager is a part of all of the theme teams and the

\section{The stages of the program process}

The iterative methodology of design-based research is exploited in the collaborative planning, implementation and evaluation of the LUMA 2020 program. Measures selected for the program are driven forward with a developing way during the entire program, and novel, suitable solutions are produced to serve as everyday actions in different levels such as inspiring operations concepts and pedagogical approaches. At the same time the collaborative continuous culture of development in the LUMA ecosystem is strengthened and established.

The systematic phases of design-based research offer a learning environment, where all participants can reflect and learn from one another, according to the 'learning community': 1) mapping out needs together with participants (empirical problem analysis, the so-called needs-analysis), 2) mapping out new research information concerning the chosen topic from sciences, their learning and teaching (theoretical problem analysis), 3) setting the aims for development together with the participants based on steps 1 and 2, 4) planning a pilot model for the object of development (e.g. an activity, material) based on set aims, 5) testing the pilot model with the target group and refining the model based on received results (multiple steps), describing the development output and reporting and 7) spreading out new openings and solutions and offering education for these new topics. During the LUMA 2020 program, the development process is carried out at least in one cycle.

The implementation of the program is divided into two main phases; development phase (from late Spring 2019 until Spring 2020) and spreading phase (from Spring 2020 until the end of 2020).

In the first phase (from late Spring 2019 until Spring 2020) LUMA Centre Finland is going to build a national network of LUMA development communities. Learning communities operating in different levels (kindergartens, primary and secondary schools, upper secondary schools and vocational institutions) are encouraged to apply. The core group of the LUMA 2020 program chooses those learning communities that are accepted to the network of LUMA development communities, this is done based on the applications. Those learning communities selected to the network of development communities are engaged with their staff in collaborative development and at the same time in education, using StarT as a tool.

In the academic year of 2019-2020, the StarT program is implementing learning projects in four various themes that those applying for the network of LUMA development communities can choose the most interesting themes for their own objects of development (and themes for projects): 1 . Sustainable development (e.g. climate change, circular economy), 2) Mathematics around us (e.g. finances, art and statistics), 3. Technology around us (e.g. a moving device, artificial intelligence, robotics) and 4. My LUMA (topic free of choice, but one that is connected to LUMA subjects). The theme teams plan concrete measures in the framework of design-based research that can be made a part of current, existing national LUMA operations. Each theme team first familiarizes with already existing LUMA operating models and their material and models that are being planned currently. This ensures that the LUMA 2020 program complements earlier LUMA programs and operations.

Together with participating learning communities that have been selected for the network of LUMA development communities, theme teams comprise aims for development and together they test implementations of novel pedagogical solutions with learning communities, especially on the level of early childhood education and upper secondary education. 
evaluation teams. If needed, teams can consult the program's experts.
Each theme may consist of an educational package for all levels (also for primary and lower secondary education) offered to the learning communities and also differentiated packages for early childhood education and upper secondary level. The packages contain inserts/examples (in the form of videos) from the program's experts and other academic specialists. The inserts can be made e.g. from the viewpoint of the program's four focal points.

Engaging education is carried out in practice with the model of blended learning, where (short) contact meetings and individual work through the online environment and especially interactions between colleagues working in different levels alternate. The staff of theme teams guide the development work for learning communities in a low-threshold online environment (e.g. in Facebook groups).

In Fall 2019 a national welcome session is organized for the staff of LUMA development communities, which is organized simultaneously in LUMA Centres in different parts of Finland. After this session, LUMA Centres organize monthly 'face-to-face' meetings ( 2 hours each) until the late Spring of 2020.

Alongside the regional StarT festivals in 2020, LUMA Centres offer educational program for the staff of LUMA development communities. The training for LUMA 2020 program's themes is in a central role in the national LUMA Days in June 2020.

The staff of learning environments test pedagogical models in their teaching that are new for them, for example by instructing the students' projectlearning and by carrying out their learning community's own StarT Day, possibly collect research data and reflect on the results in an online environment and/or in meetings together with the university personnel and with peers. They can also participate in writing research papers.

LUMA development communities are encouraged to participate in regional StarT festivals in Spring 2020 with their students' project works. Models are formed for learning communities' StarT Days and regional StarT festivals for science and technology education activities for entire families and for working life collaboration.

In addition, with these learning communities it is possible to form StarT science clubs for early childhood education and StarT clubs e.g. for the lower and upper secondary level. Here, also the staff of learning communities can test how to instruct project learning.

In the second phase (from Spring 2020 to the end of 2020), online-courses (at least 1-3) are created for themes. With the help of these it is possible to promote operations of learning communities as well as the competences of educational and teaching staff more broadly and with long-term effect, because these can be exploited even after the LUMA 2020 program in teachers' pre-service education and in support of continuous development and as a part of support for the learning community from the StarT program.

In addition, virtual club packages can be formed from the themes for small children with their families and for youth.

The purpose is that the learning communities belonging in the network of LUMA development communities operate in Fall 2020 and even after that in the roles of LUMA peer mentors for other learning communities nearby.

The contents of the LUMA 2020 program are in a central role in 2020 in all operations that LUMA Centre Finland monitors in the forums of teacher education in LUMA subjects aimed for university personnel, research on teaching and development. Through the program, the aim is to include more aspects from universities and also teacher educators from early childhood education, teacher training schools and from universities of applied sciences. Through the broadening of the forum, tripartite and four-party collaboration between operators of teacher education are promoted. 